\title{
중남미 농업 현황과 우리나라와의 개발협력의 방향1)
}

최은지 (한국농촌경제연구원 국제농업개발협력센터 연구원) 허 장 (한국농촌경제연구원 국제농업개발협력센터장)

목차

I. 서론

1. 연구 목적과 방법

2. 기존 연구 동향

II. 중남미 농업 현황

III. 중남미 지역 영농의 특성

1. 중남미 지역 영농의 유형화

2. 영농시스템별 특성

IV. 함의

$\mathrm{V}$. 우리나라 농업·농촌개발 ODA 사업 현황

VI. 중남미 권역 지원을 위한 중점 추진분야

1. 소농의 생산성 제고

2. 수자원 인프라

3. 농촌종합개발

4. 환경자원의 보전

VII. 결론

참고문헌

1) 본 논문은 한국국제협력단(KOICA)이 한국농촌경제연구원과 한국개발전략연구소(KDS)에 위탁하여 수행한 사업인 〈중남미 지역 농촌개발사업 성과중심 통합관리(2014.12 2017.2.)〉의 일환으로 진행된 3개의 연구 - (1) 중남미지역 농촌개발 지원전략, (2) 농촌개발분야 국별(파라과이, 볼리비아, 니카라과) 전략, (3) 증거기반 접근강화 적용방안 중 〈중남미지역 농 촌개발 지원전략(2015.3. 11.)〉의 주요 결과를 중심으로 재구성한 내용임을 밝힘. 


\section{국문초록}

이 연구는 중남미 지역의 농업의 현황, 영농의 특성, 우리나라의 대 중남미 ODA 현황을 파악하고, 이 지역에 특화된 우리나라의 농업개발 지원의 기본방향을 제시하는 것을 목적 으로 한다. 나라별로 식량의 생산성은 차이가 크며 농업이 국가경제에서 차지하는 비중 또한 국가별로 차이가 크다. 멕시코, 브라질, 아르헨티나를 제외하면, 중미의 열대과일과 사탕수수, 중미·남미의 커피, 남미의 대두, 쇠고기 등 농산물의 수출이 전 세계 교역량과 금액에서 높은 비중을 차지하고 있다. 우리나라와 개발협력 관계가 있는 국가가 속한 영 농시스템을 분석한 결과, 소농 및 가족농의 생산성이 낮고 환경자원 보전 프로그램에서 문제가 많은 것으로 나타났다. 1992년 이래 파라과이, 엘살바도르, 볼리비아 등의 국가 를 대상으로 시행한 농업 $\mathrm{ODA}$ 사업 22 개를 보면, 농촌종합개발, 농업기술 개발과 보급, 관개·배수 시스템 관리 분야에 집중되어 있다. 향후 중남미 농업, 농촌개발을 위해서는 (1) 소농의 생산성 제고, (2) 수자원 인프라의 개발, (3) 소득원 다양화 등 농촌종합개발, (4) 환경자원의 보전 등을 중심으로 개발협력 사업이 발굴 및 추진되어야 할 것이다.

주제어: 농업개발, 농촌개발, 영농시스템, 생산성, 공적개발원조(ODA), 개발협력

\section{I. 서론}

\section{1. 연구 목적과 방법}

지구 반대편에서 밤낮과 계절이 상반된 중남미는 그 물리적 이격만큼 우리나라와의 관계가 다 른 지역에 비해 소원하다. 2015년에 중남미를 대상으로 우리나라가 지원한 공적개발원조 (Official Development Assistance, ODA) 금액은 1,256억 원으로 전체의 6.6\%이며, 이는 아 시아(43.0\%), 아프리카(18.8\%)에 비해 크게 뒤진다. 그러나 2015년에 수립된 제2차 국제개발협 력 기본계획(2016 2020)에 중남미 4개국(볼리비아, 콜롬비아, 파라과이, 페루)이 여전히 중점적 으로 협력하여야 할 대상국에 속해 있는 등 중남미 권역과의 개발협력은 당분간 지속적으로 유지 될 것으로 보인다(관계부처합동, 2015).

이 연구는 중남미 지역의 농업의 현황, 영농의 특성, 우리나라의 대 중남미 ODA 현황을 파악 하고, 이 지역에 특화된 우리나라의 농업개발 지원의 기본방향을 제시하는 것을 목적으로 한다. 
구체적으로는, 중남미 농업의 발전과정과 현황을 소개하고, 중남미 농업이 가지는 특성을 자세하 게 살펴보기 위하여 이 지역 영농시스템을 유형화하여 유형별로 현황과 문제점, 과제를 제시하고 자 한다. 이를 위해서는 우리나라가 1992년부터 현재까지 농업 분야 ODA 실적이 있는 9개 국 가 중 카리브 해 도서국가인 도미니카(공)를 제외한 8개국(볼리비아, 에콰도르, 엘살바도르, 온두 라스, 우루과이, 콜롬비아, 파라과이, 페루)과 향후 농업관련 협력이 활발해질 것으로 전망되는 니카라과 등 총 9 개국이 포함되어 있는 영농시스템을 상세히 살펴보는 것으로 하였다. 아울러 중 남미를 대상으로 우리나라가 시행한 농업, 농촌개발 $\mathrm{ODA}$ 사업들은 어떤 것들이 있는지 살펴보고, 이들 사업들이 중점적으로 추진했던 대상 분야를 분석한다. 이러한 일련의 과정으로 도출된 분석 결과와 함의를 통해 개발협력의 중점 방향이 될 개발수요의 키워드를 파악하고, 이를 근거로 중 남미 권역에 중점적으로 추진하여야 할 분야를 4 개로 설정하고 세부 분야를 제시하였다.

〈그림 1〉연구 추진 절차

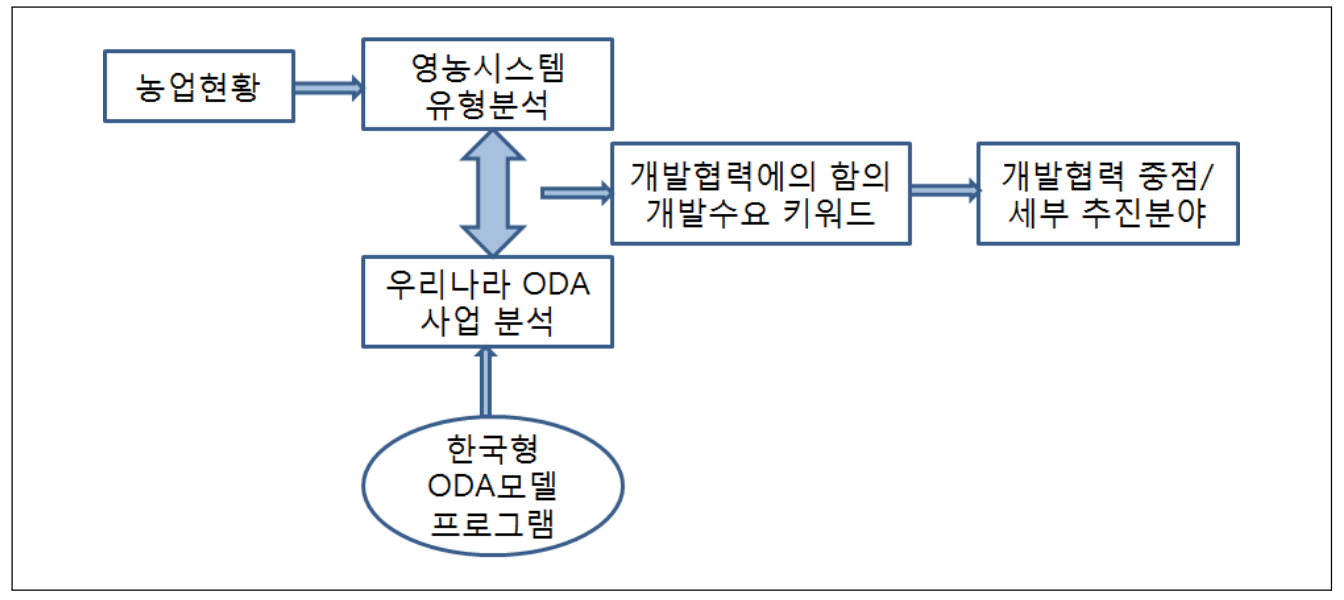

출처: 저자 작성

\section{2. 기존 연구 동향}

국제개발협력 분야에서 대 중남미 지원비율이 그다지 높지 않은 것과 같이 중남미 권역을 대 상으로 한 농업, 농촌분야 연구는 해외농업개발이나 개발협력 혹은 ODA사업 관련 보고서를 제 외하고는 매우 드물다. 농산물 순수입국인 우리나라가 곡물자급률을 높이기 위해 브라질, 아르헨 티나 등 세계적인 곡물생산국의 농업생산과 유통 등을 분석한 것으로 김동환(2011)이 있으나 이 는 개발협력의 관점이 아닌 자원개발의 관점에서의 연구이다. 농업내 세부분야별 현황과 문제점 등에 관해서는 한국농촌경제연구원의 정기간행물인「세계농업」에서 커피산업(강지현, 2012), 와 
인산업(정대희 외, 2013), 브라질의 면화, 유지종자, 설탕과 에탄올 산업(이동소 외, 2013; 윤영 석, 2013; 신용광, 2014), 칠레 양돈과 포도산업(허덕, 2013; 김경필, 2014) 등이 있다. 이 밖 에 칠레, 멕시코, 페루, 파라과이, 콜롬비아, 엘살바도르, 아르헨티나, 과테말라, 에콰도르, 니카 라과, 브라질 등 중남미 국가의 농업에 관한 일반현황 자료가 정리된 것들도 찾아볼 수 있다(세 계농업 2013.1 2016.4 각 호 참조).

중미, 남미, 카리브해 국가 등 세부권역별 혹은 개별 국가의 현황과 개발수요, 전망 등에 대한 연구가 이 분야에서 이루어지고 있으나 중남미 권역 전체를 대상으로 한 농업 및 농촌 개발협력 에 초점을 맞춘 연구는 찾아보기 힘들 정도이다. 이는 중남미가 매우 다양한 지리적 여건과 농업 환경을 가지고 있기에 권역 전체를 아우르는 섹터별 연구가 힘들다는 점을 반영하기에 당연할 수 있다. 그러나 우리나라의 개발협력이 권역의 농업, 농촌의 특징과 함께 부문별로 우리나라의 비 교우위를 반영한 중장기 전략에 따라 추진되어야 하고, 이를 기초로 국가별 협력전략이 수립되어 야 한다는 점에서, 중남미 권역을 대상으로 한 개발협력의 방향을 제시하는 것은 의의가 있다고 하겠다.

우리나라가 ODA 예산의 증가속도는 매우 빠르지만 미국, 일본 등 선진 공여국에 비하여 아직 그 규모는 적은 편이다. 따라서 이를 효과적, 효율적으로 투입하는 것이 무엇보다도 중요하며, 이를 반영하여 우리나라 정부는 중점협력국가를 선정하여 이들 국가를 대상으로 한 국별협력전략 (Country Partnership Strategy, CPS)을 수립하고 중점 추진사업 분야를 제시하고 있다. 대상 국의 수요를 적절히 반영하여 중점 추진분야를 설정하는 일은 우리나라 및 대상국의 국내외 여 건, 정책적 판단 등 다양한 요소가 개입되므로 매우 어려운 일이다. 가령 허태호(2013)는 중남미 는 농업생산기술에 관심이 많으나 한국국제협력단의 무상원조는 농촌개발에 대한 지원이 가장 많 아, 수원국의 발전단계와 수요보다는 한국의 경험이 많은 분야를 중심으로 사업이 일률적으로 진 행된다고 주장하였다. 이러한 점을 고려할 때, 중남미 권역에 대한 섹터별 현황을 파악하고 이로 부터 잠재적 수요를 도출하여 중점협력 추진분야를 설정함으로써, 권역내 국가별 농업분야 협력 의 전략을 수립하는데 함의를 도출하는 것은 효과적인 접근방법이 될 수 있다. 


\section{II. 중남미 농업 현황}

대부분의 개도국이 마찬가지이지만 중남미의 경우에도 농업은 토지이용, 노동력 활용 뿐만 아 니라 경제발전과 환경을 위해서도 국가경제에서 가장 중요한 산업이다(하상섭, 2010b: 74). 카 리브 해 연안 국가들을 포함하여 중남미 지역의 농업생산성은 그 성장속도가 지난 1961 2007 년 기간에 연평균 $1.9 \%$ 에 불과하여, $\mathrm{OECD}$ 국가의 $2.4 \%$ 에 미치지 못한다. ${ }^{2}$ 그러나 칼로리 기 준으로 볼 때 현재 이 지역 인구가 필요로 하는 식량보다 더 많이 생산하고 있어서 식량의 가용 성(availability)에서는 문제가 없는 것으로 보고되고 있다(FAO, 2015: 9). 남미의 경우에는 생 산된 식량의 $50 \%$ 가량이 수출된다(하상섭, $2010 \mathrm{~b}: 80$ ). 물론 식량의 생산성에서는 나라별로 차 이가 크게 나타난다. 아르헨티나와 우루과이는 농업생산성(농업노동력 대비 생산가치)이 각각 9,987 달러, 9,064 달러임에 비하여 볼리비아는 733 달러에 불과하다(ECLAC 외, 2012: 44).

제 I 장

제 II 장

제 III장

지

역

제 $\mathbb{N}$ 장 농업이 국가경제에서 차지하는 비중 역시 국가별로 차이가 크다. 2012년 기준으로 콜롬비아는 1 차 산업의 비중이 $6.8 \%$ 인 반면에 파라과이는 $22 \%$ 를 차지한다(관계부처합동, $2012 \mathrm{a} ; 2012 \mathrm{~b}$ ).

$\mathrm{UN}$ 식량농업기구(FAO)의 자료를 보면, 중남미 전체(멕시코, 브라질, 아르헨티나 포함) 지역 은 품목별 생산량을 기준으로 세계 커피 생산의 $57 \%$, 콩 $22 \%$, 사탕수수 $50 \%$, 오렌지 $38 \%$, 쇠 고기 $27 \%$, 닭고기 $23 \%$, 옥수수 $15 \%$ 를 차지하고 있다. 그러나 농업대국인 멕시코 등 3 개국을 제외하면 커피는 $20 \%$, 콩 $4 \%$, 사탕수수 $6 \%$, 오렌지 $4 \%$, 쇠고기 $5 \%$, 닭고기 $6 \%$ 로 그 비중이 감소한다. ${ }^{3)}$ 곡물의 경우 브라질, 아르헨티나, 멕시코 3 국이 중남미 전체 연간 생산량의 $80 \%$ 이 상을 차지하고 나머지를 30 개국에서 생산하는 등 극심한 편중 현상을 보이고 있다(FAO, 2015: 10). 또한 브라질은 전 세계 사탕수수의 $34 \%$, 설탕의 $18.5 \%$, 에탄올의 $37 \%$ 를 생산한다(돌나라 통상, 2014).

축산의 경우 세계 가축의 $14 \%$ 가 이 지역에서 사육되고 있다. 이 분야에서도 브라질이 남미 전체 가축 가운데 육우, 유우, 돼지의 절반, 가금류의 $40 \%$ 를 차지한다(ECLAC 외, 2012: 53). 브라 질은 세계 최대의 소 사육국가(2억 마리)이자 쇠고기 수출국이기도 하다(돌나라 통상, 2014).

중남미의 농업은 농산물 수출에 의존하는 구조로, 세계 농산물 수출의 $10 \%$ 가량을 담당하고 있다. 또한 전체 수출 중 약 $20 \%$ 를 농산물이 차지하는 반면에, 수입에서 농산물이 차지하는 비 율은 8\% 정도이어서 농산물 순수출 지역이라고 할 수 있다(ECLAC 외, 2012: 38, 45). 그러나 베네수엘라, 파나마, 엘살바도르 등은 농식품(가공식품 포함) 순수입국으로, 중남미 역내에서도

2) IDB. "Latin American Agriculture Statistics." 〈http://www.iadb.org〉 (접속일: 2016.08.12.)

3) FAO. "FAOSTAT." 〈http://faostat.fao.org〉(접속일: 2015.09.15.) 
차이를 보이고 있다(FAO, 2015: 11). 수출량 기준으로는 중남미 전체적으로는 전 세계 수출량 가운데 콩 $17 \%$, 옥수수 $24 \%$, 커피 $51 \%$, 포도 $31 \%$, 닭고기 $32 \%$ 등을 차지한다. 그러나 멕시 코, 아르헨티나, 브라질을 제외하면 콩은 $4 \%$, 옥수수 $1 \%$, 닭고기 $1 \%$ 에 불과하다. 단, 커피는 $23 \%$, 포도 $25 \%$ 로 3 국을 제외해도 상당량을 수출하고 있다. ${ }^{4)}$

〈표 1〉 중남미 곡물 생산

(단위: 천 톤)

\begin{tabular}{c|r|r|r}
\hline \multirow{2}{*}{} & \multicolumn{3}{|c}{ 연평균 } \\
\cline { 2 - 4 } & $1990-99$ & $2000-09$ & $2010-15$ \\
\hline 중남미 전체 & 113,956 & 151,385 & 200,210 \\
\hline 남미 & 82,307 & 114,349 & 160,229 \\
\hline 아르헨티나 & 27,883 & 35,231 & 48,317 \\
\hline 브라질 & 39,855 & 58,276 & 85,069 \\
\hline 중미 & 31,649 & 37,035 & 39,982 \\
\hline 쿠바 & 411 & 684 & 780 \\
\hline 엘살바도르 & 813 & 864 & 987 \\
\hline 과테말라 & 1,250 & 1,320 & 1,827 \\
\hline 멕시코 & 26,762 & 31,409 & 33,361 \\
\hline
\end{tabular}

출처: FAO (2015: 10)

국가별로 특정 품목에의 수출의존도가 높은 경우가 많이 나타나고 있다. 대두는 파라과이가 세 계 생산량 기준 6 위에 세계 4 위의 수출국이고, 파라과이 수출의 $35 \%$ 를 차지한다(관계부처합동, 2012b). 페루의 경우 유기농커피 수출의 선두국가이며, 커피는 페루 농산물 수출량의 $35 \%$, 전체 수출량의 $5 \%$ 를 차지한다(이재훈, 2013). 콜롬비아는 1980년 이래 세계 2 위의 커피 생산, 수출 국이다(관계부처합동, 2012a).

한편 아래 〈표 2〉에서는 중미, 남미지역의 농축산물 생산 및 수출이 전 세계에서 차지하는 비 율과 더불어, 멕시코를 제외한 중미 7 개국, 브라질과 아르헨티나를 제외한 남미 10 개국이 전 세 계에서 차지하는 비율을 제시하였다. 이에 따르면, 중미 지역에서는 멕시코를 제외하더라도 커피 와 사탕수수는 그 생산 비중이 크게 줄지 않는다. 남미의 경우, 세계적인 농업대국인 브라질, 아 르헨티나를 제외하게 되면 대부분의 농축산물이 전 세계에서 차지하는 생산, 수출의 비중이 급감 함을 알 수 있다. 포도의 경우 수출에서의 비중이 큰 차이를 보이지 않으나, 실제로는 칠레와 페 루에 집중되어 있고 나머지 나라들은 그 생산과 수출이 미미하다. 대두는 브라질을 제외하면 파 라과이에 생산과 수출이 집중되어 있다.

4) FAO. "FAOSTAT.”〈http://faostat.fao.org〉 (접속일: 2015.09.15.) 


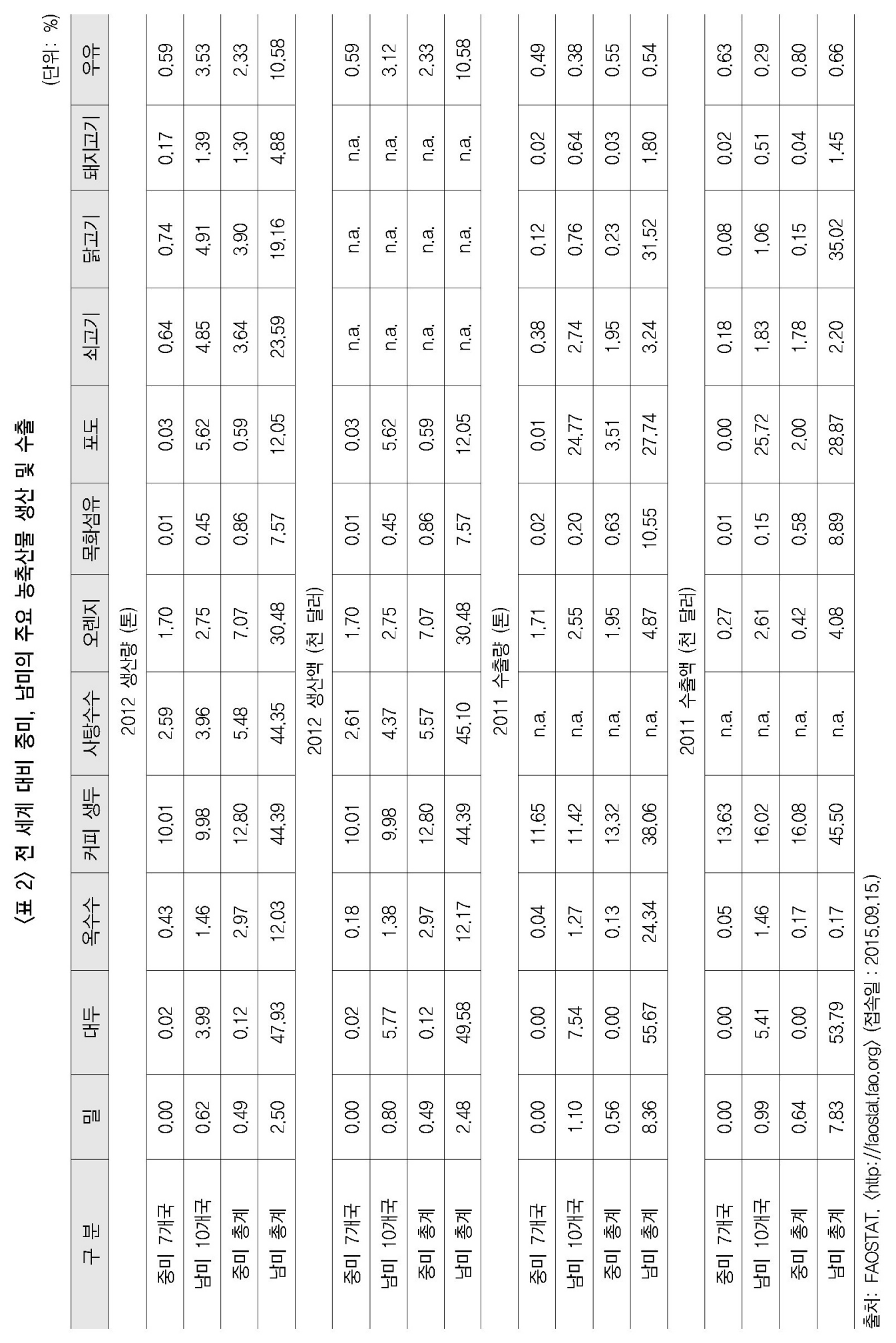

제 I 장

제 II 장

제 III 장

지

제 $\mathbb{N}$ 장 
수출의 비중을 국가별 농산물 수출의존도와 수출의존 품목을 중심으로 살펴보면 다음과 같다. 이에 따르면 국가별로 농산물의 수출의존도가 크게 차이가 나서 벨리즈, 파나마, 가이아나, 파라 과이, 우루과이 등은 $60 \%$ 를 상회하는 반면, 베네수엘라, 수리남, 콜롬비아, 볼리비아 등은 석유 와 각종 광물자원의 수출 비중이 워낙 커서 농산물의 수출 비중은 높지 않다. 그러나 후자의 국 가일수록 광물자원에의 의존도가 높아 국제곡물가격의 변동성에 의해 자국의 식량안보가 위협 받 을 수 있다.

〈표 3〉국가별 농산물의 수출의존도와 주력 품목

(단위: \%)

\begin{tabular}{|c|c|c|}
\hline 국 가 & 수출의존도 & 수출 주력 품목 \\
\hline 벨리즈 & 76.6 & 오렌지, 설탕, 바나나 \\
\hline 코스타리카 & 34.5 & 파인애플, 바나나, 커피 \\
\hline 엘살바도르 & 19.1 & 커피, 설탕 \\
\hline 과테말라 & 42.4 & 커피, 설탕, 바나나 \\
\hline 온두라스 & 56.9 & 커피, 팜오일, 바나나 \\
\hline 니카라과 & 51.5 & 커피, 쇠고기 \\
\hline 파나마 & 67.5 & 바나나 \\
\hline 볼리비아 & 15.9 & 대두박 \\
\hline 칠레 & 22.5 & 건포도 \\
\hline 콜롬비아 & 9.2 & 커피 \\
\hline 에콰도르 & 35.3 & 바나나 \\
\hline 가이아나 & 65.7 & 쌀, 설탕 \\
\hline 파라과이 & 65.1 & 대두, 쇠고기 \\
\hline 페루 & 23.6 & 커피 \\
\hline 수리남 & 1.8 & 바나나, 쌀 \\
\hline 우루과이 & 65.3 & 대두, 쇠고기 \\
\hline 베네수엘라 & 0.0 & 커피 \\
\hline
\end{tabular}

주: 전체 상품수출 중 농식품 수출비중임. 2014년 자료이며, 단 벨리제, 코스타리카, 콜롬비아, 베네수엘라는 2013년, 온두 라스는 2012년, 수리남은 2011년 자료임.

출처: World Bank 〈data.worldbank.org/indicator/TX.VALFOOD.ZS.UN〉 (접속일: 2015.08.12.); FAOSTAT〈http://faostat.fao.org〉 (접속일: 2015.09.15.)

이상에서 본 바와 같이 중남미의 농업은 멕시코, 브라질, 아르헨티나를 제외하면, 중미의 열대 과일과 사탕수수, 중미·남미의 커피, 남미의 대두, 쇠고기 등 농산물의 수출이 전 세계 교역량 과 금액에서 높은 비중을 차지하고 있다. 
한편 중남미는 식민지 시대부터 이어진 토지의 집중으로 극소수 대농과 대다수 소농으로 나뉘 어 식량안보와 사회적 통합에 위협이 되어 왔다. 가령, 파라과이는 농가 $1 \%$ 가 전체 토지면적의 $77 \%$, 농가 $62 \%$ 가 전체 토지면적의 $22 \%$, 농가 $37 \%$ 가 전체 토지면적의 $1 \%$ 를 점유하고 있다(관 계부처합동, 2012b). 이는 농촌주민의 빈곤과도 직접적으로 연계되며, 소농의 생산성 제고를 위 한 기술보급, 조직화, 각종 서비스 제공은 중남미 농정의 핵심이 되고 있다.

\section{III. 중남미 지역 영농의 특성}

\section{1. 중남미 지역 영농의 유형화}

중남미 지역은 역사, 문화, 지리 뿐만 아니라 기후, 농지 종류 등 농업에 영향을 미치는 요인 이 매우 다양하다. 따라서 중남미 지역의 농업 특성을 보다 세부적으로 분석하기 위해서는 중남 미 지역의 영농시스템이 가지고 있는 특성을 도출해 볼 필요가 있다. 이 연구에서는 이를 위해 국제연합 식량농업기구(Food and Agriculture Organization, FAO)와 세계은행(World Bank) 이 2001년 발간한 '영농시스템과 빈곤(Farming System and Poverty)'에서의 영농시스템 분류 결과를 활용하였다(FAO·World Bank, 2001). 이 문서는 세계은행의 농촌개발전략 수정에 활용 하는 것을 목적으로 $\mathrm{FAO}$ 가 작성한 것으로, 개발도상국을 위주로 세계 주요 영농시스템을 70 여 개로 분류하고 있다. 또한 주요 영농시스템과 관련된 도전과제 및 기회와 빈곤퇴치를 위한 전략 의 방향 등도 제시하였다.

영농시스템은 물, 토지, 방목 영역, 산림, 기후, 영농규모 등과 주요 영농활동 및 작물생산, 축 산, 농업기술력 등 생계수단 패턴을 기준으로 분류하였다. 70 여 개로 분류된 유형 가운데 15 개 의 유형이 중남미 지역에서 발견된다. 이들 15 개의 영농 시스템별 주요 작물과 해당 국가는 아래 〈표 4〉와 같다. 
〈표 4〉영농시스템별 주요 생계수단 및 해당 국가

\begin{tabular}{|c|c|c|c|}
\hline & 영농시스템 & 주요 생계수단 & 해당 국가 \\
\hline 1 & 관개농업 & 원예, 과일, 소 & 페루, 칠레, 베네수엘라 \\
\hline 2 & 임업기반 농업 & 자급형 농업, 목축업 & $\begin{array}{c}\text { 브라질, 수리남, 가이아나, } \\
\text { 베네수엘라, 콜롬비아, 에콰도르, } \\
\text { 페루, 볼리비아 }\end{array}$ \\
\hline 3 & 해안 플랜테이션 및 혼합농업 & $\begin{array}{c}\text { 수출 작물, 임목, 어업, 구근류, } \\
\text { 관광업 }\end{array}$ & $\begin{array}{c}\text { 베네수엘라, 가이아나, 수리남, } \\
\text { 기아나, 브라질, 콜롬비아, 에콰도르, } \\
\text { 파나마, 코스타리카, 니카라과, } \\
\text { 온두라스, 과테말라, 멕시코, 쿠바, } \\
\text { 도미니카(공), 푸에르토리코 }\end{array}$ \\
\hline 4 & 집약적 혼합농업 & 커피, 원예, 과일, 농업 외 소득 & 브라질 \\
\hline 5 & 곡물 및 축산업 (캄푸스) & 쌀, 축산 & $\begin{array}{c}\text { 브라질, 우루과이, 아르헨티나, } \\
\text { 파라과이 }\end{array}$ \\
\hline 6 & 습윤 지역 혼합농업 및 임업 & 낙농업, 소, 곡류, 임업, 관광업 & 칠레 \\
\hline 7 & $\begin{array}{l}\text { 옥수수 및 콩류 혼합농업 } \\
\text { (메조아메리칸) }\end{array}$ & $\begin{array}{c}\text { 옥수수, 콩, 커피, 원예, 농업 외 } \\
\text { 소득 }\end{array}$ & $\begin{array}{l}\text { 파나마, 코스타리카, 니카라과, } \\
\text { 온두라스, 과테말라, 멕시코 }\end{array}$ \\
\hline 8 & $\begin{array}{c}\text { 집약적 고원지대 혼합농업 (안데스 } \\
\text { 북부) }\end{array}$ & $\begin{array}{c}\text { 채소, 옥수수, 커피, 소, 돼지, } \\
\text { 곡물, 감자, 농업 외 소득 }\end{array}$ & 에콰도르, 콜롬비아, 베네수엘라 \\
\hline 9 & $\begin{array}{l}\text { 조방적 혼합농업 } \\
\text { (쎄하도, 야노스) }\end{array}$ & 축산, 오일시드, 곡물, 커피 & $\begin{array}{c}\text { 브라질, 베네수엘라, 볼리비아, } \\
\text { 콜롬비아 }\end{array}$ \\
\hline 10 & 온대지역 혼합농업 (팜파스) & 축산, 밀, 대두 & 아르헨티나, 우루과이 \\
\hline 11 & 건조지역 혼합농업 & 축산, 옥수수, 카사바, 임금노동 & 브라질, 멕시코 \\
\hline 12 & $\begin{array}{c}\text { 조방적 건조지대 혼합농업 } \\
\text { (그란차코) }\end{array}$ & 축산, 목화, 자급용 농작물 & 아르헨티나, 파라과이, 볼리비아 \\
\hline 13 & 고산지대 혼합농업 (안데스 중부) & $\begin{array}{c}\text { 구근류, 양, 곡류, 라마, 채소, } \\
\text { 농업 외 소득 }\end{array}$ & 페루, 볼리비아, 칠레, 아르헨티나 \\
\hline 14 & 목축업 & 양, 소 & 아르헨티나 \\
\hline 15 & 한계 이하 농업생산 지역 (삼림) & 양, 소, 임업 생산물, 관광업 & 칠레 \\
\hline
\end{tabular}

출처: FAO · World Bank(2001: 265)를 정리한 것임

이 연구에서는 앞서 언급한 바와 같이 1992년 이후 한국국제협력단(KOICA) 및 대외경제협력 기금 $(\mathrm{EDCF})$ 이 농업 · 농촌개발 분야에서 $\mathrm{ODA}$ 사업을 시행한 적이 있는 국가 8 개국 및 니카라과 가 속한 7 개 영농시스템에 대해서 집중적으로 살펴보고자 한다. 


\section{2. 영농시스템별 특성}

\section{1) 해안 플랜테이션 및 혼합농업}

카리브해에 접하고 있는 니카라과, 콜롬비아, 에콰도르 북부 등이 해당된다. 중남미 지역 중 가장 양질의 농업용 토양을 가지고 있다. 지대가 낮고 비옥한 토양 외에도 일부 맹그로브 습지와 열대 우림을 포함하고 있다. 자급을 위한 소규모 가족농과 바나나, 사탕수수 등의 수출용 작물 재배를 위주로 하는 대규모 플랜테이션 농가로 구분할 수 있다(FAO, 2001: 263).

소규모 농업인들의 대다수는 바나나를 재배하여 소득을 얻고 있으나 치키타브랜즈인터내셔널 (Chiquita Brands International), 돌(Dole), 델몬트(Del Monte) 등의 다국적 식품기업들의 대 량 생산으로 인해 시장에서 경쟁력을 잃고 있다. 또한 이 지역은 허리케인으로 인한 농업 피해가 해마다 발생하고 있다. 수출 작물에 대한 높은 의존도와 이로 인한 취약성, 기후변화에 대한 미 비한 대응책이 이 지역 주요 문제점이다.

\section{2) 옥수수 및 콩류 혼합농업}

니카라과, 온두라스 등 대다수 중미 국가들이 이 시스템을 포함하고 있다. 주로 자급을 위한 옥수수와 대두가 생산되며 고도 $500 \mathrm{~m}$ 이상의 지형에서는 커피가 재배된다. 많은 원주민들이 과 거 식민지 지배의 영향과 상업화로 인해 영세농화하여 저임금노동을 통해 소득을 얻는다. 관개시 설이 되어 있는 농지 대부분은 커피, 육우, 고무, 절화(cut flower) 등을 생산하는 대규모 농업 인들이 소유하고 있다(FAO, 2001: 285).

이 지역에서는 토지문제의 해결이 중요한 과제이며, 특히 $0.5 \mathrm{ha}$ 규모의 분절화된 소규모 농가 의 생산성 향상이 필요하다. 커피와 같은 수출 작목은 세계 시장의 가격 변동에 취약하다.

\section{3) 임업기반 농업}

아마존 유역을 포함하여 중남미 지역의 $30 \%$ 를 차지한다. 연중 강수가 많고 토질은 다양하다. 콜롬비아 남부, 에콰도르 남부, 페루 동부, 볼리비아 북부 등이 여기에 속한다. 자급형 농업 활동 과 조방적 축산 및 일부 플랜테이션 농업이 있다. 인구 밀도가 1 ha 당 0.02 명 수준으로 매우 낮 다(FAO, 2001: 263). 아마존 지대의 경우 이동경작(shifting cultivation)을 해왔으나 최근 대 두, 팜 오일 등 수출용 작물 재배 및 소 방목의 증가로 무분별한 산림 벌채가 곳곳에서 행해지고 있다. 불법개간, 화학비료의 무분별한 사용 등 지속가능하지 않은 방식의 농업활동, 방목 확대에 따른 토질 훼손 및 산림벌채가 주요 문제점이다. 


\section{4) 집약적 고원지대 혼합농업}

안데스 산맥 북부 콜롬비아와 에콰도르 등의 영농시스템으로, 산간 계곡과 산기슑을 따라 소농 에 의한 커피와 원예를 주로 재배하는 영농시스템, 온대성 작물 및 옥수수 재배와 돼지 사육을 주로 하는 토착민들이 거주하는 고원지대 및 상부 계곡으로 나뉜다(FAO, 2001: 264). 콜롬비아 의 절화 산업은 네덜란드에 이어 세계 2위 규모이다(Meier, 1998: 275). 에콰도르 안데스 지역 에서는 옥수수, 밀, 보리, 감자, 두류 등의 자급용 농업 및 식용작물이 주로 생산된다.

이 지역 역시 농업활동, 산림 벌채, 방목, 그리고 엘니뇨 등으로 솦, 습지에 부정적 영향을 미 치고 있다. 콜롬비아 안데스 지역은 코카인 대규모 재배로 인한 산림 파괴 및 하천 오염 문제와 함께 폭력, 범죄, 실향민 문제가 발생하고 있다.5)

\section{5) 고산지대 혼합농업}

중앙 안데스의 페루 남부와 볼리비아 남부가 여기에 해당된다. 토양의 종류, 해발고도, 온도, 습도, 강수량 등이 다양하다(FAO, 2001: 291). 강수량이 적은 편이며 평균 기온은 $10^{\circ} \mathrm{C}$ 이하 로, 건조기에는 서리가 자주 내린다. 영농 활동의 대부분은 해발 $3,200 \mathrm{~m}$ 이상의 고산지대에서 생산이 가능한 곡물 및 감자 재배, 양 및 라마와 같은 방목 방식의 가축사육이 주를 이룬다 (FAO, 2001: 266). 고원지방의 극단적인 영농 생태환경, 분절된 토지소유권, 조방적 방목, 메마 른 토지, 농업 외 소득창출 기회의 결여 등으로 인해 빈곤 정도가 매우 심각하다.

\section{6) 조방적 건조지대 혼합농업}

남미 중앙의 평원지대로 그란차코(Gran Chaco)라고 불리며, 아마존 유역 다음으로 남미에서 가장 큰 생태계 집중 지역으로, 볼리비아 동남부와 파라과이 서부가 포함된다. 지정학적 위치, 반건조 환경, 우기 시의 홍수문제, 불량한 토양 등으로 인해 농업 및 경제·사회 개발 가능성은 상당히 제한적이다(FAO, 2001: 266). 관개시설이 거의 없고 거주 인구가 매우 적으며 거주민 대부분인 원주민들의 빈곤율이 높다. 주요 생산 활동은 축산, 목화 및 자급용 농작물 재배에 집 중되어 있다.

수출을 위한 목화, 대두와 같은 환금작물 재배, 과도한 방목, 아울러 명확하지 않은 토지 소유 권 등으로 인한 환경 및 천연자원, 산림파괴 문제가 대두되고 있다.

5) Council on Hemispheric Affairs. "Colombia's Invisible Crisis: Internally Displaced Persons." 〈http://www.coha.org〉 (접속일: 2015.08.03.) 


\section{7) 곡물 및 축산업}

캄푸스(Campos) 초원지대를 포함하며 파라과이 동부와 우루과이가 여기에 속하는데 벼농사와 목축업이 이루어지고 있다. 목축업의 경우 비효율적인 자원관리, 최신기술 도입의 한계, 서비스 구조의 결여, 낙후된 육우 시장, 작은 농가 규모 등으로 생산력이 낮은 편이다. 단위 면적당 방 목률이 높아 장기적으로 초원 황폐화 및 생산력 저하가 우려된다. 토양이 척박하여 목축업에 비 해 곡물 생산은 한정적이다. ${ }^{6)}$ 파라과이 캄푸스(Campos)의 경우 곡물류 재배 농가 $80 \%$ 이상이 소 규모 농가이다.7)

최근 대두 재배가 빠른 속도로 증가하나 미가공 수출이 많고 농기계를 사용하기 때문에 부가 가치 획득과 농촌 고용 증대를 기대하기는 어렵다. 아울러 단일 작물 재배로 인한 환경문제, 토 착민들의 삶의 터전 위협, 브라질, 아르헨티나 등 대규모 농업자본의 장악이 문제로 지적된다(하 상섭, 2012 ; 김세건, 2010).

제 I 장

제 II 장

젶I장

\section{IV. 함의}

중남미는 하나의 대륙이지만 해안농업에서 안데스 지역의 건조, 고산지대의 농업까지 매우 다 양한 영농 생태계를 가지고 있다. 아울러 국가별로 농업의 경제, 사회적 비중도 서로 다르다. 위 에서 본 바와 같이 중남미 농업은 플랜테이션에서 다국적 기업이 생산, 수출하는 형태를 제외하 고는 소농, 가족농에 의하여 농축산물을 생산하는 형태로 되어 있다. 이들은 식민시대를 거치면 서 극심한 토지소유의 불균등에 의해 저소득 상태에 놓이는 '역사적 빈곤' 뿐만 아니라, 신자유주 의와 세계화로 인한 '새로운 빈곤'에 직면하고 있다(정상희, 2016: 61).

이러한 조건을 고려하여 농업부문에서는 다음과 같이 세 가지 분야에 초점을 맞춘 개발 및 협 력전략이 수립되어야 할 것이다.

첫째, 소농, 가족농을 중심으로 한 지원 프로그램이 필요하다. 농촌의 발전과 국가 전체의 발 전은 같은 방향으로 진행되며, 농촌의 발전은 농촌내 소농, 가족농의 경제적, 사회적 여건을 개 선함으로써 이루어질 수 있다. 이를 위해서는 생산성 제고를 위한 기술개발과 보급이 필수적이 며, 규모화를 위한 영농 및 유통에서의 조직화, 생산자재의 공급이 필요하다. 소농에 대한 지원 은 이들이 축산업에 크게 의존하는 가구의 비율이 높다는 점에서 가축질병 등 재난 대비, 축산 생산성 제고와 부가가치 확대를 위한 서비스의 도입도 필요하다(ECLAC 외, 2012: 64).

6) FAO. "The South American Campos Ecosystem."〈http://www.fao.org〉 (접속일: 2015.08.25.)

7) FAO. "Paraguay."〈http://www.fao.org〉 (접속일: 2015.08.25.) 
둘째, 빈곤층이 다수 분포하는 오지지역은 (1) 농촌내 비전통적 농업, 즉 자가소비용 농업이 아 닌 다변화된 농업과 (2) 농촌관광 등 비농업 부문과 연계된 경제활동 등 다변화된 농촌경제 (diversified rural economy)를 지향하고, 이밖에 보건의료 등 기초수요에 대응하는 농촌종합개 발 프로그램을 도입하는 것이 효과적이다.

셋째, 관리가 제대로 되지 않는 방목형 축산업과 임업으로부터 위협받고 있는 산림과 초지를 보호하고, 기후변화에 대응하기 위한 지속가능한 농림축산업이 필요하다. 사료용 콩, 축산용 초 지 조성 등을 위해 해마다 $0.3 \sim 0.4 \%$ 의 산림이 벌채(deforestation)되고 있다(ECLAC 외, 2012: 58). 산림벌채의 속도가 느려지고 관련제도가 도입되는 등 이 지역 환경보호를 위한 정책 이 시행되고 있지만 보다 적극적으로 관련 프로그램의 발굴과 시행이 필요하다(ECLAC 외, 2012: 80, 82). 시설내 집약적(intensive) 축산의 확대 등이 제안되고 있으나 동물복지와 환경 오염, 적정입지의 어려움 등을 고려할 때 근본적인 해결방안은 아니며, 산림에서의 경제활동과 농업을 결합시키는 이른바 혼농임업(agro-forestry)이나 비목재 임산물(non-timber forest products, NTFP) 생산의 장려 등이 좋은 대안일 수 있다.

이상에서 분석한 중남미 농업의 현황과 영농시스템, 함의를 요약하면 다음과 같다.

〈표 5〉 농업현황과 영농시스템 분석결과로부터의 함의 및 키워드

\begin{tabular}{c|c|c}
\hline 분석결과 & 함 의 & \multicolumn{1}{c}{ 키워드 } \\
\hline 〈중남미 농업현황〉 & (1) 소농, 가족농을 중심으로 한 지 & \\
원 프로그램 : 생산성 제고를 & \\
(1) 중미는 열대과일과 사탕수수, 커피, & 위한 기술개발과 보급, 규모화를 \\
남미는 커피, 대두, 쇠고기 등을 & 위한 영농 및 유통에서의 조직 & (1) 소농(가족농)의 생산성 제고 \\
대량으로 생산하는 국가가 많음. & 화, 생산자재의 공급, 가축질병 & (2) 기술개발 및 보급 조직화 \\
(2) 일부 국가는 농산물의 수출이 전 & 등 재난 대비, 축산 생산성 제고 & (3) 생산자재와 기계화 \\
세계 교역량과 금액에서 높은 비중 & 와 부가가치 확대를 위한 서비 & (4) 가축사양 및 생산성 제고 \\
을 차지하는 등 농산물 수출이 중 & 스의 도입 & (5) 농업 서비스 \\
요한 부분을 차지함. & (2) 생계형 농업이 아닌 다변화된 & (6) 소득원 다양화 \\
농촌경제로 소득원을 다양화하 & (7) 기초수요 고려한 농촌종합개발 \\
영농시스템 분석결과〉 & 고, 기초수요에 대응하는 농촌종 & (8) 지속가능 농업 \\
(1) 소농 혹은 가족농의 생산성 제고에 & 합개발 프로그램으로 오지 빈곤 & \\
초점 필요 & 마을 개발 & \\
(2) 환경자원의 보전과 관련된 농림축 & (3) 지속가능한 농림축산업의 관련 & \\
산업 프로그램 필요 & 프로그램의 적극 시행 & \\
\hline
\end{tabular}

출처: 저자 작성 


\section{V. 우리나라 농업·농촌개발 ODA 사업 현황}

공적개발원조 $(\mathrm{ODA})$ 사업은 프로젝트, 프로그램, 개발컨설팅, 초청연수 봉사단 파견, 기타기술

협력, 민관협력, 장학지원 등으로 구분된다. 이 가운데 프로젝트 사업은 개도국의 경제사회 발전 에 필요한 특정 시설 - 인프라의 구축, 기자재 지원 및 이와 관련된 기술전수 등의 사업이다. 우 리나라가 1992년부터 현재까지 완료하였거나 추진 중인 대 중남미 ODA 프로젝트형 사업은 총 163 개로, 이 가운데 농업 · 농촌 관련 사업은 22 개(13\%)를 차지한다(아래〈표 6〉 참조).

이들 프로젝트 사업의 내용은 '한국형 ODA모델'에서의 협력 프로그램에 근거하여 분석했다. 한국형 ODA모델은 2012년 정부가 우리의 정책경험, 비교우위 등을 고려하여 분야별로 총 159 개의 협력 프로그램을 선정하고 이를 중심으로 $\mathrm{ODA}$ 사업을 추진하도록 제안한 것이다. 이 가운 데 농림업 분야는 식량작물 생산성 제고, 농촌종합개발, 산림녹화 등 20 개의 프로그램이 제시되 어 있다(허장 외, 2012).

중남미에서 시행된 농업, 농촌 개발협력 프로젝트는 농촌종합개발 사업 9 개, 농업기술 개발 및 지도보급체계 구축사업 8 개, 관개 - 배수 시스템 개발 및 관리 분야 5 개로, 대부분 이 세 분야에 집중되어 있다. 국가별로는 파라과이와 엘살바도르에 각 4 개, 볼리비아에 3 개의 프로젝트가 진행 되었다.

〈표 6〉농업 · 농촌 관련 중남미 ODA사업

\begin{tabular}{|c|c|c|}
\hline 대상국가 & 사업명 & 한국형 ODA 협력프로그램 중 해당분야 \\
\hline \multirow{2}{*}{$\begin{array}{l}\text { 도미니카 } \\
\text { 공화국 }\end{array}$} & 도미니카(공) 농촌지역 초등학교 건축사업 & 농촌종합개발 \\
\hline & $\begin{array}{l}\text { 도미니카(공) 농촌지역학교 교실건축사업 } \\
\text { (농촌지역 2차 초등학교 건립사업) }\end{array}$ & 농촌종합개발 \\
\hline \multirow{3}{*}{ 볼리비아 } & 추키사카주 저수용 댐 축조 및 관개수로 건설사업 & 관개 · 배수 시스템 개발 및 관리 \\
\hline & 산타크루스주 몬테베르데지역 관개용 지하수 개발사업 & 관개· 배수 시스템 개발 및 관리 \\
\hline & $\begin{array}{l}\text { 고원지역 농업기계화 및 농민 역량강화를 통한 생산성 } \\
\text { 증대 지원사업 }\end{array}$ & 경제작목 재배 및 시설원예, 영농 기계화 \\
\hline \multirow{2}{*}{ 에콰도르 } & $\begin{array}{l}\text { 에콰도르 침보라소주 관개수로 건설 및 영농기술지원 } \\
1 \text { 차 사업 }\end{array}$ & $\begin{array}{l}\text { 관개·배수 시스템 개발 및 관리, 농업기술 } \\
\text { 개발과 현장지도 지원 시스템 }\end{array}$ \\
\hline & $\begin{array}{l}\text { 에콰도르 침보라소주 글로벌 새마을사업 } \\
\text { (관개수로 건설 및 영농기술지원 2차 사업) }\end{array}$ & $\begin{array}{l}\text { 관개 · 배수 시스템 개발 및 관리, 농업기술 } \\
\text { 개발과 현장지도 지원 시스템 }\end{array}$ \\
\hline \multirow{4}{*}{ 엘살바도르 } & 농촌식수공급시설 지원사업 & 농촌종합개발 \\
\hline & 엘살바도르 채소재배 생산성 향상 & 경제작목 재배 및 시설원예 \\
\hline & 농업 및 식량안보를 위한 농업기술 역량강화사업 & 농업기술 개발과 현장지도 지원 시스템 \\
\hline & 쌀생산성 향상을 위한 관개 개발사업 & 관개 · 배수 시스템 개발 및 관리 \\
\hline
\end{tabular}




\begin{tabular}{c|l|l}
\hline 대상국가 & \multicolumn{1}{|c|}{ 사업명 } & \multicolumn{1}{|c}{ 한국형 ODA 협력프로그램 중 해당분야 } \\
\hline \multirow{4}{*}{ 온두라스 } & 온두라스 라빠즈 농업기술훈련원 현대화 & 농업기술 개발과 현장지도 지원 시스템 \\
\cline { 2 - 3 } & 온두라스 감자경쟁력 향상사업 & 농업기술 개발과 현장지도 지원 시스템 \\
\cline { 2 - 3 } & 농촌 태양광 전력화사업 & 농촌종합개발 \\
\hline \multirow{2}{*}{ 우루과이 } & 우루과이 국립농업연구소 벼 생리연구능력 강화사업 & 농업기술 개발과 현장지도 지원 시스템 \\
\hline 콜롬비아 & 농촌 지역 빈곤퇴치사업 & 농촌종합개발 \\
\hline \multirow{5}{*}{ 파라과이 } & 벽촌지역 식수공급시설 사업 & 농촌종합개발 \\
\cline { 2 - 3 } & 국립농업연구소지원 & 농업기술 개발과 현장지도 지원 시스템 \\
\cline { 2 - 3 } & 농촌개발시범사업 & 농촌종합개발 \\
\cline { 2 - 3 } & 파라과이 국립 농축산 기술훈련센터 건립사업 & 농업기술 개발과 현장지도 지원 시스템 \\
\hline \multirow{3}{*}{ 페루 } & 페루 꼬라오 농촌지역개발 사업 & 농촌종합개발 \\
\cline { 2 - 3 } & 농촌개발사업(새마을운동) & 농촌종합개발 \\
\hline
\end{tabular}

출처: 한국수출입은행. “ODA 통계."〈http://www.edcfkorea.go.kr〉 (접속일: 2015.07.01.)

우리나라가 시행한 대 중남미 농업 · 농촌개발 분야 ODA사업의 특징은 다음과 같다. 우선, 농 촌종합개발로 분류되는 분야에 과도하게 집중된 경향을 보인다. 농촌종합개발은 사회, 문화적으 로 동질적인 농촌지역에 대하여 지역주민의 기초수요를 충족시키고 시설물 설치와 장비 제공 등 하드웨어와 주민 역량개발, 기술이전과 같은 소프트웨어를 동시에 추구한다는 점에서 바람직한 개발방식의 하나이다. 그러나 소규모 분산된 사업이 시행됨에 따른 비효율성, 사업관리의 어려움 등의 문제도 안고 있다(허장, 2014: 69). 향후에는 종합적 개발의 수요가 있고 그 필요성이 명확 한 경우에 한하여 시범적으로 추진할 필요가 있다.

한편으로는 농업기술개발과 보급(현장지도 지원), 수자원 관리를 위한 관개· 배수 시스템 등은 우리나라와 국제사회가 공통적으로 추구하는 지원전략 및 프로그램들이며, 따라서 바람직한 방향 이라고 할 수 있다. 그럼에도 불구하고 우리나라 ODA 사업의 내용이 3 4가지 주제, 프로그램 으로 집중하는 것은 바람직하지 않을 수 있다. 이것은 대상국의 다양한 수요를 기존의 협력사업 틀에 무리하게 맞추어 추진할 우려가 있기 때문이다. 따라서 대상국가와 지역, 개발수요, 그리고 사업마다의 특성에 따라 보다 다양하게 방향과 사업내용을 설정할 필요가 있다. 


\section{VI. 중남미 권역 지원을 위한 중점 추진분야}

이상에서는 중남미 농업의 생산, 무역 등에 관한 기본 현황, 주요 국가별 영농 시스템, 그리고 우리나라의 대 중남미 농업, 농촌관련 $\mathrm{ODA}$ 사업의 특징 등을 분석하고 개발협력에의 함의를 제 시하였다. 아울러 이 지역에서의 개발협력사업에 대한 수요를 키워드로써 파악하였다. 이를 토대 로 이하에서는 중남미 권역의 농업, 농촌발전을 위한 개발협력의 중점 추진 분야를 선정, 제안하 고자 한다. 중점 추진분야는 우리나라가 이 지역에서 향후 개발협력 사업을 발굴하고 시행하기 위하여 우선적으로 고려하여야 하는 사업 분야가 될 것이다. 또한 중점추진분야는 그 안에 개별 $\mathrm{ODA}$ 프로젝트로 발전할 수 있는 세부 분야를 포함하며, 따라서 이는 '프로젝트의 패키지’라는 의 미에서의 '프로그램'이라고 할 수도 있을 것이다.8)

중점 추진분야는 다음 네 가지이다. 첫째, 농축산업에 종사하는 소농의 생산성 제고를 위한 프 로그램으로 농업기술 개발과 보급, 조직화, 자재의 공급 및 기타 서비스(금융, 재난 대응 등)를 제공할 필요가 있다. 둘째, 수자원 개발과 관리, 관개 시스템 구축 등 물 관련 인프라를 설치하 도록 지원한다. 셋째, 농업 및 농외소득원 다양화와 기초수요 충족을 포함한 지역단위 농촌종합 개발을 지원한다. 넷째로는 이들 중점 추진분야가 중남미 권역의 지속가능한 발전이 될 수 있도 록 산림, 토양 등 환경자원을 보전하는 방식으로 추진되도록 한다. 중점 추진분야별 세부 분야는 다음과 같다.

〈그림 2〉 중남미 권역 농업 · 농촌개발 지원 중점 추진분야와 세부 분야

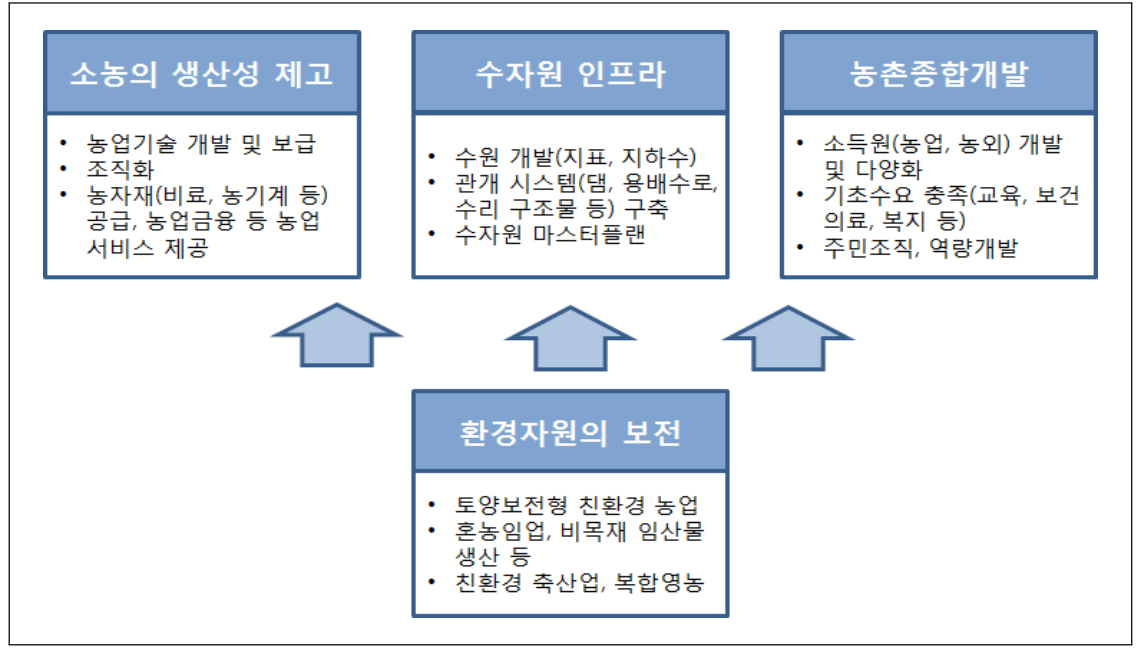

출처: 저자 작성

8) 프로그램과 프로젝트의 개념에 대해서는 이현주(2010) 참조 


\section{1. 소농의 생산성 제고}

중남미는 원주민 등 소수자에 대한 차별 철폐와 사회적 통합을 위해 많은 노력을 기울이고 있 는데, 특히 이들의 생계수단인 농업을 통한 지원정책을 많이 도입하고 있다. 콜롬비아가 안데스 태평양 연안에 500만 ha에 달하는 토지를 공동체 토지로 배정한다든가 볼리비아, 니카라과가 원 주민 공동체에게 토지소유권 혹은 이용권을 인정하는 것이 그 예이다(박찬호 외, 2011a: 351; 2011b: 제4장 제2절). 이는 식민지 시절부터의 아시엔다, 라티푼디움 등 대농장 플랜테이션이 발달하면서 토지소유에서의 극단적인 불균형으로 농촌주민의 빈곤이 심각하다는 점을 반증한다. 플랜테이션 농업은 농업의 산업화, 상품화로 근대화에 많은 도움을 준 반면, 세계경제에의 종속 과 부의 유출, 원주민 등 미니푼디아스(minifundias)라고 불리는 소농의 노동력을 수탈하였다는 비난도 받는다(하상섭, 2010a; 2010b: 81).

따라서 소농의 생산성 제고를 통한 소득증대와 빈곤해결이 중요한 과제이다. Trejos· Montiel(1999)은 토지 생산성이 증대될 경우 코스타리카의 빈곤한 농민들 $90 \%$ 이상이 가난에서 벗어날 수 있음을 증명한 바 있다(Justino et al., 2003: 15에서 재인용). 이는 단순한 토지소유 권 문제를 넘어 양질의 토지에 대한 접근성 및 새로운 기술과 시장 확보 측면의 접근 방식이 필 요함을 시사한다(Justino et al., 2003: 15; Kay, 2006: 456). 이를 위해 소농 경영체제에 적 합한 농업기술, 가령 신품종의 연구 개발과 보급 조직, 체계를 구성하는 것이 필요하다. 우리나 라는 1960 년대 말 농촌진흥청이 벼의 다수확 신품종('통일벼')을 개발하고 이를 지방의 보급기관 (농촌지도소 등)을 통해 신속히 농민에게 보급함으로써 1970년대에 쌀 자급을 이룩하였다(허장 정승은, 2014: 24).

지역 특산물이나 경쟁력이 있는 농산물을 중심으로 작목반 등 조직을 구성하여 농산물의 수집, 포장, 운송 등 유통과 시장에서의 판매 등을 공동으로 추진한다. 이를 통해 상인에 대한 교섭력 을 강화하거나 직거래로써 유통상의 부가가치를 확보할 수 있을 것이다.

비료 등 생산에서의 투입재와 농기계 등은 단위면적당 혹은 투입 노동력당 생산량을 제고시킬 수 있는 효과적인 방법이나, 소농 등 빈곤한 농민은 이와 같은 자재의 구입이 어려운 실정이다. 따라서 자재구입 비용과 농기계 이용 서비스 비용 등에 대한 금융지원(micro-credit 등) 등 농 업서비스의 도입이 필요하다.

\section{2. 수자원 인프라}

대다수 중남미 국가의 관개 효율성은 30 40\% 범위에 속하는 낮은 수준으로 농업분야에 있어 
수자원의 효율적인 활용은 생산성 증대에 크게 기여할 것으로 기대된다(Davila, 2011). 하상섭 (2011)은 중남미에서 수자원 관리 및 관개농업 시스템 구축은 IMF, 세계은행이 빈곤감축의 일환 으로 적극 추진하는 분야로, 개도국 정부의 관리능력의 회복, 기후변화 대응과 적응 등의 측면에 서도 잠재성이 뛰어난 새로운 개발협력 분야라고 주장한다. 볼리비아의 경우 자국의 수자원 관리 정책(PRONAR)의 지속적 수행을 위해 국제사회에서의 지원이 필요하며, 우리나라가 이를 위한 비교우위와 발전경험을 가지고 있다고 보았다.

수자원은 영농을 위한 가장 기본적인 인프라로, 농업생산을 위한 기반시설이다. 규모의 경제를 실현하면서 생산성을 높이고 가뭄 혹은 홍수로 인한 재난과 실농을 예방하기 위하여 필수적이다. 수자원 인프라는 수원의 확보뿐만 아니라 확보된 수자원을 효율적으로 사용할 수 있도록 농지로 배분한 뒤 배수할 수 있도록 1 3차 수로(canal)로 된 체계를 구축하는 것이 필요하다.

수원으로는 지표수(하천, 저수지, 호수 등)와 지하수가 있으며, 지하수의 경우 중금속이나 유

제 I 장

제 II 장

제표장 기물 등에 의해 오염되지 않았는지 수질을 확인하여야 한다. 농장에 공급되는 수량의 조절을 위 한 갑문 등 조절장치(regulators)의 적절한 설치가 될 수 있도록 하는 것도 중요하다.

무엇보다도 수자원 활용을 위한 전국적 혹은 지역 · 수계별 종합개발계획(master plan)을 수 립할 필요가 있다. 우리나라의 경우 1960 년대에 전국적으로 기본조사를 거쳐 농업용수 개발계획 을 수립하였다. 그 뒤 1970 1980년대에는 용수개발, 배수개선, 경지정리, 개간과 간척 등 수자 원개발을 농지의 효율적 활용과 연계시킨 대단위 농업종합개발사업을 추진하였다. 이 과정에서 계획 실천을 위한 조직(농업진흥공사, 토지개량조합 등)을 구성하고 관련 법령들이 제정되었다(이 남호, 2014).

\section{3. 농촌종합개발}

농촌종합개발은 소득원을 개발하며, 농촌이 농산물 공급지로서의 기능 이외에 지역주민들이 거 주하는 정주공간으로서의 기능을 가져야 한다는 점을 강조하는 방식이다(허장, 2014: 1). 최근의 국제적인 식량안보 및 영양(Food Security and Nutrition, FSN) 정책은 농업 등 산업중심의 관점에서 벗어나 지역적(territorial) 접근, 즉 농촌발전을 통한 다면적 전략을 강조하고 있다 (OECD, 2016), 중남미의 경우 빈곤해결과 환경자원 보호를 위해서도 농촌에 대한 투자와 인프 라 구축이 필요할 것이다(하상섭, $2010 \mathrm{~b}: 84$ ). 농촌종합개발은 지역 특산물의 생산과 공급, 농촌 공업, 지역의 유형 및 무형자원을 활용한 관광상품의 개발 등 모든 소득원의 개발이 포함된다. 소득원 개발에는 지역주민의 창의적 소재 발굴 이외에도 외부 전문 인력에 의한 컨설팅도 중요한 역할을 할 수 있다. 
학교(유치원 포함)나 1차적 보건의료 시설, 복지시설의 공급과 위생교육 등 주민들의 기초수요 를 충족시키는 것이 필요하다. 특히 교육기회의 확대로 인적자본을 양성하고 보건위생과 의료 혜 택을 통해 건강한 지역사회의 기반을 구축할 때 빈곤한 상태를 극복할 수 있는 여건이 마련될 수 있다.

아울러 각종 시설물의 운영을 위한 기술 습득, 협동조합 등 공동 활동을 통한 소득창출과 부가 가치의 확대는 주민의 조직화와 역량개발을 통해 가능하다. 여기에는 스스로 지역사회의 자원을 동원하기 위한 중장기 개발계획의 수립 등도 포함된다.

\section{4. 환경자원의 보전}

중남미는 그란차코 등 광활한 토지를 중심으로 이루어지는 목축업, 사탕수수와 바나나 등 열대 플랜테이션으로부터의 단작재배(mono-culture), 기후변화 등으로 지역에 따라 다양한 환경문제 를 안고 있다. 특히 최근에는 유전자변형 대두, 밀을 중심으로 초국적 곡물기업들(카길, AGD, 벙기 등)이 아르헨티나, 브라질 등에 진출하면서 이로 인한 식량주권의 문제와 더불어 환경피해 의 우려도 제기되고 있다(하상섭, 2012: 172-173).

친환경농업은 토양을 비롯한 농업자원에의 화학적 투입재를 최소화하는 농업이므로 소농, 가족 농에게 적합한 영농방식이다. 아울러 여러 농작물을 재배하여 농업생태계의 다양성을 유지시킴으 로써 건강한 자연환경을 유지하는데 도움이 된다. 친환경 농자재의 개발과 공급, 친환경농업 직 접지불제(Direct Payment), 우수농산물관리제도(Good Agricultural Practice, GAP)나 친환경 농산물 및 그 가공품에 대한 인증제의 도입, 소비지와의 직거래에 대한 지원 등의 정책 도입을 지원하도록 한다.

산림분야에서의 협력을 통해 환경자원을 보전하는 것은 특별히 효과적이다. 장수환 외(2014) 는 국제 산림협력이 기후변화, 사막화 방지, 생물다양성 관리의 세가지 이슈에서 국제적 환경문 제에 대응해왔다고 언급하였다. 경제적으로 지속가능한 개발을 위해서는 한편으로는 양묘, 조림 및 재조림과 같은 임산자원 개발과 산림녹화 등 전통적 프로젝트 이외에도 버섯 등과 같은 비목 재 임산물(non-timber forest products, NTFP) 생산을 장려하고, 조림목 사이에 원예작물을 경작하여 소득을 올리는 혼농임업(agro-forestry)을 도입함으로써 산림자원을 보전할 필요가 있 다. 지역주민과 정부 등 이해당사자들이 관심을 가지고 참여하는 지역산림관리(community foresty management, $\mathrm{CFM}$ ) 프로그램은 이러한 친환경적 산림경영 방식을 포괄적으로 도입할 수 있는 방안이다(허장 외, 2013: 129). 
축산업에서도 경종과 축산을 결합하는 복합영농(Integrated Crop-Livestock System, ICLS) 을 통해 경종이나 축산업에만 전념함에 따른 위기를 분산하고 곡물 생산성을 안정화, 제고하여야 할 것이다. 이밖에 생태계 보호서비스 지원(Ecosystem Service Payments, ESP) 방안으로서 정책을 이행하는 대가로 보조금을 지급하는 직접지불제(Direct Payment)의 도입, 친환경 축산물 인증제 시행 등과 같은 제도의 도입과 개선을 위한 컨설팅, 마스터 플랜 수립이 시급한 지원 분 야가 될 것이다(ECLAC 외, 2012).

\section{VII. 결론}

이 연구는 중남미 지역의 농업 현황을 살펴보고 이를 토대로 이 지역의 농업 개발 촉진에 크 게 기여할 가능성이 높은 세부 분야를 선별하고자 하였다. 중남미 지역 농업의 현황과 문제점을 파악하기 위해 우선 이 지역 농업 생산 및 수출 동향을 살펴보고, 좀 더 미시적인 분석을 위해 영농형태별 주요 특성과 도전과제를 도출하였다. 이를 우리나라의 대 중남미 농업·농촌개발 프 로젝트형 $\mathrm{ODA}$ 사업 중점 추진분야와 비교함으로써 실제 이 지역에 지원이 필요한 세부 분야와 지금까지의 우리나라 $\mathrm{ODA}$ 추진 방향 간에 간극 존재 여부를 진단하였다.

중남미 농업 특성을 고려하였을 때 소농 및 가족농의 생산성 제고를 중심으로 한 지원, 다변화 된 농업 및 농촌경제 기반 마련을 위한 농촌종합개발 프로그램, 수자원 인프라, 환경자원을 고려 한 지속가능한 농림축산업을 중심으로 한 지원이 가장 큰 효과가 있을 것으로 판단된다. 그 동안 우리나라는 주로 농촌종합개발, 농업기술개발과 보급, 관개· 배수 시스템 분야에 집중적으로 지 원을 해왔는데 향후에는 빈곤 심화 지역을 중점적으로 보다 집중화된 농촌개발 시범사업 및 소농 과 지속가능한 농업자원을 중심으로 사업내용의 다양화가 필요할 것으로 보인다.

본 연구는 중남미 지역의 국별 ODA 지원전략 수립 시 참고가 될 농업분야 ODA 기본방향을 제시하고 있다. 위에서 기술한 바와 같이 중남미는 국가별로 농업 비중, 영농생태계 등이 매우 다양하다. 그러나 농민들의 영농활동 및 생계수단 패턴을 중심으로 구분한 중남미 영농시스템의 경우 영농시스템별로 적게는 1 개 국가에서 많게는 16 개 국가가 포함된다. 따라서 농업분야 국별 지원전략 수립 시 지역적 차원에 대한 고려가 반드시 동반되어야 할 것이다. 영농시스템별 현황 분석에서 토양 등 물리적인 환경이 크게 변하지 않았을 것이라는 가정 하에 2001년에 발간된 자료에 의존해야 했는데, 좀 더 신뢰성 높은 분석 결과를 위해서는 물리적 환경 변화 여부 등에 대한 파악을 위한 현지 조사가 이루어져야 할 것이다. 또한 $\mathrm{ODA}$ 효과성을 높이고 공공 지원을 
통한 우리나라의 위상 제고 측면에서 중남미와의 농업개발 협력 중점 추진분야로 제시된 세부 분 야별로 주요 국제기구 및 해외 원조기관은 어느 정도나 지원하고 있는지에 대한 현황 파악도 필 요할 것이다. 이를 통해 국제적 지원 규모가 상대적으로 적지만 동시에 우리나라의 강점이 있는 분야를 파악하고 이를 중점협력 추진분야와 연계시킬 수도 있을 것이다. 


\section{〈참고문헌〉}

강지현. 2012. “중남미 및 아시아 커피산업 동향.” 『세계농업』 제145호: 1-9. 나주: 한 국농촌경제원

관계부처합동. 2015. “2016년 국제개발협력 종합시행계획”. 세종: 국무조정실

제 I 장

제 II 장

제 III장 2012a. “콜롬비아 국별협력전략(CPS) 2013-2015”. 세종: 국무조정실 2012b. “파라과이 국가협력전략(CPS) 2013-2015”. 세종: 국무조정실

김경필. 2014. “칠레 포도산업 동향.” 『세계농업』 제165호: 1-12. 나주: 한국농촌경제원 김동환. 2011. "남미 농업진출을 위한 밸류체인 분석 : 브라질과 아르헨티나를 중심으로."

『신유통포커스』. 서울: 농식품신유통연구원

김세건. 2010. “파리과이 농촌의 세계화와 농민의 저항: ‘콩 전쟁’을 중심으로.” 『이베로 아메리카』12(1): 55-86. 부산: 부산외국어대학교 이베로아메리카 연구소

돌나라통상. 2014. 『해외농업개발 매뉴얼(브라질)』

박찬호 외. 2011a. “글로벌 전략수립을 위한 지역 기초 연구.” 세종: 한국법제연구원 2011b. “글로벌 전략수립을 위한 지역 현안 보고서.” 세종: 한국법제연구원

신용광. 2014. “브라질 설탕 및 에탄올산업 동향.” 『세계농업』제171호: 1-12. 나주: 한 국농촌경제원

윤영석. 2013. “브라질 유지종자산업 동향.” 세계농업』제156호: 1-14. 나주: 한국농촌 경제연구원

이남호. 2014. “한국형 ODA 모델 중 농림업 분야 국제협력 프로그램의 심화 연구-농업 생산 기반.” 나주: 한국농촌경제원

이동소·이기현. 2013. “브라질 면화 생산과 정책 동향." 『세계농업』제153호: 1-15. 나 주: 한국농촌경제원

이재훈. 2013. “지역전략산업 개발계획: 커피.” 2012 경제협력국가와의 경제발전경험 공 유 사업(페루): 96-122』. 세종: 기획재정부

이현주. 2010. “한국 ODA의 프로그램형 접근법(PBA) 도입방안.” 성남: 한국국제협력단 장수환-장유운. 2014. "한-중남미 산림분야 국제협력 방향 연구: 노르웨이와 일본의 대 브라질 산림협력 분석을 기반으로.” 포르투갈-브라질 연구』11(2): 61-90. 천안: 한 국포르투갈-브라질학회

정대희·정구현. 2013. “북·남미 와인산업 동향." 『세계농업』 제149호: 117-134. 나주: 한국농촌경제원 
정상희. 2016. 『중남미 국제개발협력 입문』. 대구: 계명대학교

하상섭. 2012. “아르헨티나 식량안보와 식량주권 위기: GM 대두생산 사례 연구." 중남 미연구』31(2): 161-189. 서울: 한국외국어대학교 중남미연구소

. 2011. "남미 볼리비아 수자원 관리 및 관개농업 시스템 개선을 위한국제개발협

력.”국제개발협력』제2호: 108-139. 성남: 한국국제협력단

2010a. “중미 국가들의 통합과 발전의 딜레마: 지정학적 환경문제, 식민지배 및

정치경제 저발전의 유산.” 한국행정학회 비정기학술발표논문집』제5호: 64-86. 서울:

한국외국어대학교 중남미연구소

. 2010b. “라틴아메리카 농업의 지속가능한 발전." 『국제지역정보』 제 174 호:

123-147. 서울: 한국외국어대학교 국제지역연구센터

허덕. 2013. “칠레 양돈산업 동향과 시사점." 『세계농업』제157호: 1-22. 나주: 한국농 촌경제연구원

허장. 2014. “한국형 ODA 모델 중 농림업 분야 국제협력 프로그램의 심화 연구-농촌종 합개발.” 나주: 한국농촌경제연구원

허장-이대섭 - 정승은. 2012. "한국형 ODA 모델 수립을 위한 농어업 분야 ODA 프로그

램 선정연구.” 나주: 한국농촌경제연구원

허장 - 정승은 · 유병일. 2013. “한국의 농업분야 ODA사업 정책 · 전략 및 농림분야 협력전 망 분석.” 나주: 한국농촌경제연구원

허장. 정승은. 2014. "한국형 ODA 모델 중 농림업 분야 국제협력 프로그램의 심화 연구농업기술 개발 및 현장지도 지원시스템.” 나주: 한국농촌경제연구원

허태호. 2013. "농업 ODA의 효과성 제고를 위한 수원국 개발수요 중요도 분석." 경제학 석사학위 논문. 춘천: 강원대학교

Davila, Caridad Canales. 2011. "Water and the Green Economy in Latin America and the Caribbean: Regional Context and Lessons Learned." UN-Water International Conference 발표자료(2011.06.03-05). ECLAC

ECLAC · FAO - IICA. 2012. "The Outlook for Agriculture and Rural Development in the Americas: A Perspective on Latin America and the Caribbean." Santiago: FAO

FAO. 2015. "Regional Overview of Food Insecurity: Latin America and the Caribbean.” Rome: FAO 
FAO and World Bank. 2001. "Farming Systems and Poverty: Improving Farmers' Livelihoods in an Changing World.” Rome \& Washington, DC: FAO \&World Bank

Justino, Patricia et al. 2003. "The Impact of Inequality in Latin America." University of Sussex: Working Paper 21. Brighton: University of Sussex

Kay, Cristobal. 2006. "Rural Poverty and Development Strategies in Latin America." Journal of Agrarian Change』6(4): 455-508. Oxford: Blackwell Publishing Ltd

Meier, V. 1999. "Cut-flower production in Colombia-a major development success story for women?" 『Environment and Planning』. 31: 273-289. London: Sage Publications

OECD. 2016. "Adopting a Territorial Approach to Food Security and Nutrition Policy.” Paris: OECD

\section{〈각종 자료 및 통계 웹사이트〉}

한국수출입은행. “ODA 통계.”〈http://www.edcfkorea.go.kr〉 (접속일: 2015.07.01.)

Council on Hemispheric Affairs. "Colombia's Invisible Crisis: Internally Displaced Persons.”〈http://www.coha.org〉 (접속일: 2015.08.03.)

FAO. “FAOSTAT.”〈http://faostat.fao.org〉(접속일: 2015.09.15.)

. “The South American Campos Ecosystem.”〈http://www.fao.org〉(접속일: 2015.08.25.)

. "Paraguay.”〈http://www.fao.org〉 (접속일: 2015.08.25.)

IDB. "Latin American Agriculture Statistics."〈http://www.iadb.org〉 (접속일: 2015.08.12.)

World Bank. "the World Bank Open Data."〈data.worldbank.org〉 (접속일: 2015.09.15.) 